\title{
Funding Applicant
}

National Cancer Institute

\section{Source}

National Cancer Institute. Funding Applicant. NCI Thesaurus. Code C19465.

Someone applying for financial support from $\mathrm{NCl}$ to do research, training, or other work 